\title{
The Association of Gene Expression and Single Nucleotide Polymorphism (rs 6152 SNP) in Androgen Receptor Gene with Recurrent Spontaneous Abortion (RSA) in Iraqi Women
}

\author{
Shireen Hamid Farhan', Ismail A. Abdul-Hassan² \\ ${ }^{1}$ Scholar Researcher, Department of Pathological Analysis, Applied Science, University of Fallujah, Iraq, ${ }^{2}$ Scholar \\ Researcher, Institute of Genetic engineering and Biotechnology for postgraduate studies, University of Baghdad,
} Iraq

\begin{abstract}
The proposal target was determining the gene expression and single nucleotide polymorphism of Androgen receptor gene (rs6152 G>T) in blood sample of recurrent spontaneous abortion (RSA) Iraqi females. Fifty females $(n=50)$ with RSA consulted Al-Elwiya teaching hospital from February to June 2019 and apparently healthy fertile control $(n=50)$ were enrolled. DNA and RNA were extracted from leucocytes to detriment the SNP and gene expression which were carried out by (RT-q PCR). The results showed non -significant difference $(\mathrm{p}>0.05)$ in the mean of threshold cycle $(\Delta \mathrm{Ct})$ of androgen receptor gene between female with RSA and control. Assessing the $2-\Delta \Delta \mathrm{Ct}$ in female with RSA, non -significant decreased expression of folding in androgen receptor $m$ RNA compared with control. The genotypes and allele frequencies in the two groups showed significant decrease in the heterozygous (GA) and mutant (AA) genotype frequencies in female with RSA, the frequency of wild (GG) genotype is increased in female with RSA. In conclusion, expression of androgen receptor gene didn't affect in female with RSA, the mutant genotype may play as protective SNP against RSA.
\end{abstract}

Keywords: Androgen receptor gene, gene expression, single nucleotide polymorphism and recurrent spontaneous abortion.

\section{Introduction}

Losing more than three or more repeated pregnancies before 20 weeks referred to as Recurrent spontaneous abortion (RSA), its multifactorial disorder including uterine anomaly, chromosomal abnormalities, endocrine and immune dysfunction, life style and maternal infections ${ }^{(1)}$. Androgens are sex steroid hormones found in male and female and play a role in the physiological function of many organs such as hypothalamus adrenal gland, thyroid gland, pituitary gland mammary gland, heart, liver, kidney, ovaries, uterus epididymis prostate and seminal vesicles, also androgens regulate the growth and secondary sex characteristics ${ }^{(2)}$. In females the normal ovary secretes three major steroid androgens: androstenedione, testosterone and dehydroepiandrosterone by the stroma (interstitial tissue) and by the theca interna cells ${ }^{(3)}$ androgens production is very important for decidualization, a process that controls embryo implantation and placentation ${ }^{(4)}$.
Recent researches which are interest in females' health suggest that the testosterone hormone ((one form of androgens)) plays role in many medical conditions such as recurrent miscarriage, polycystic ovary syndrome, androgenic alopecia, hirsutism, acne and many various conditions ${ }^{(5)}$.

Androgens mediate their actions via the androgen receptor AR a ligand -dependent nuclear transcriptional factor $^{(6)}$. AR belongs to the steroid hormone nuclear receptor family, its expressed in different tissues and plays a biological action in bone, muscle, prostate, adipose tissue, cardiovascular, immune, neural and reproductive system ${ }^{(7)}$. AR activated by testosterone or dihydrotestosterone and the activated AR is transferred into the nucleus where it regulates the transcription of genes $^{(8)}$.

Uncontrolled AR signalling through activation of $A R$ via phosphorylation of the AR which is called ligand- 
independent activation involves in the development of tumours in prostate, bladder, liver, kidney and lung ${ }^{(9)}$.

\section{Subjects, Material and Method}

This study included fifty females $(\mathrm{n}=50)$ who had idiopathic RSA (mean age $35.06 \pm 0.9$ ) and consulted Al Elwiya teaching hospital, Baghdad, Iraq between January 2019 and April 2019 and fifty normal fertile females $(n=50)$ with at least 2 live births and without history of abortion. Patients with anatomical, infection, endocrine metabolic disorder and autoimmune diseases were excluded from the study. Ethical approval for the study was obtained from Al Elwiya teaching hospital.

DNA extraction and genotypes analysis: The DNA was extracted from blood by using kit (QuickgDNA тм Blood MiniPrep, Zymo research/USA), Nanodrop was used to estimate the purity and the concentration for DNA samples. Genotyping analysis was performed using Real Time PCR by predesigned TaqMan fluorescent oligonucleotide probes and primers ordered from integrated DNA technologies/USA for examined SNP rs6152 in exon 1 of androgen gene were stored lyophilized at $-20^{\circ} \mathrm{C}$. Taq man SNP genotyping assay using real time thermocycler according to the protocol recommended by the manufacturer as showed in table (1) and (2).

Table (1) The component reaction.

\begin{tabular}{|l|c|}
\hline Component & $\mathbf{2 0} \boldsymbol{\mu l}$ (Final volume) \\
\hline 2X TaqMan ${ }^{\circledR M a s t e r ~}$ & $10 \mu \mathrm{l}$ \\
\hline 20X Assay Working & $1 \mu \mathrm{l}$ \\
\hline Nuclease - free & - \\
\hline DNA sample volume & $9 \mu \mathrm{l}$ \\
\hline
\end{tabular}

Table (2) The thermocycler program

\begin{tabular}{|l|c|c|c|}
\hline \multirow{2}{*}{ Steps } & \multicolumn{2}{|c|}{ Predesigned SNP } \\
\cline { 2 - 4 } & Temperature & Duration & Cycles \\
\hline Enzyme activation & $95^{\circ} \mathrm{C}$ & 10 Minutes & Hold \\
\hline Denaturation & $95^{\circ} \mathrm{C}$ & 15 Seconds & \multirow{2}{*}{40} \\
\hline Annealing extension & $60^{\circ} \mathrm{C}$ & 1 Minute & \\
\hline
\end{tabular}

RNA extraction and gene expression: The expression of androgen receptor gene was determined by the reverse transcription quantitative polymerase chain reaction ( $\mathrm{RTqPCR}$ ) method after isolation of total RNA. A ready-to-use reagent (TRIzolTM LS Reagent; Thermo Fisher Scientific; USA) was used to isolate total RNA. The isolated RNA was reversely transcribed to cDNA using prime Script ${ }^{\mathrm{TM}} \mathrm{RT}$ reagent Kit. The reverse transcription quantitative polymerase chain reaction (RT-
qPCR) was carried out using the KAPA SYBER FAST qPCR Master Mix Kit (Universal, Germany) and cDNA as a template. Forward and reverse oligonucleotide primers of androgen receptor gene were designed and showed in table (3). The forward and reverse primers of the housekeeping gene GAPDH (reference gene: glyceraldehyde-3-phosphate dehydrogenase) were also given.

Table (3) The primers of gene expression.

\begin{tabular}{|l|c|c|c|}
\hline Primer & Sequence & Tm ( $\mathbf{(} \mathbf{C})$ & GC (\%) \\
\hline Forward of androgen receptor gene & TCACATCTGGTTCAATGCTCA & 54.3 & 42.9 \\
\hline Reverse of androgen receptor gene & TGAGAGCACTGGATGCTGTT & 56.5 & 50 \\
\hline Forward of GAPDH (reference gene & AGGTCATCCCTGAGCTGAA & 52.1 & 45 \\
\hline Reverse of GAPDH (reference gene & CTGCTTCACCACCTTCTTGAT & 55.6 & 47.6 \\
\hline
\end{tabular}


The reaction mix was adjusted to a final volume of $20 \mu \mathrm{l}$ as suggested by the manufacturer, and included: $10 \mu 1$ KAPA SYBR FASR_qPCR Master Mix (2X), for 2-Step RT-qPCR, $0.4 \mu 1$ of each primer $(0.2 \mu \mathrm{M})$, $3 \mu \mathrm{cDNA}$, and nuclease-free water. The mix was transferred to a real time thermocycler (Sacace Realtime PCR System, Italy), which was programmed for the following optimized cycles: initial denaturation for 5 min at $95 \mathrm{C}^{\circ}$ (one cycle), 40 cycles of denaturation (20 sec. at 95 _ ), annealing ( $20 \mathrm{sec}$. at $\left.56 \mathrm{C}^{\circ}\right)$ and extension (20 sec. at $72 \_$C ), and finally one cycle of melt curve ( $15 \mathrm{sec}$. at $90 \mathrm{C}$ ). The expression was given as $2^{-} \Delta \Delta \mathrm{Ct}$, which represents the relative fold change. Therefore, the results were expressed as a fold change in the expression level of a target gene that was normalized to endogenous control (housekeeping gene) and relative to a calibrator, which is the target gene in control subjects

Statistical Analysis: The Statistical Analysis System- SAS (2012) program was used to detect the effect of difference factors in study parameters. Least significant difference -LSD test (Analysis of Variation-
ANOVA) was used to significant compare between means. Chi-square test was used to significant compare between percentage ( 0.05 and 0.01 probability). Estimate of Odd ratio and CI IN this study ${ }^{(10)}$.

\section{Results}

Genotype and allele frequency of androgen receptor gene: The rs6152 SNP that examined in this study because there was an association with RSA in a different population (Mexicans, Greek and Iranian) and the interest to further examination of this SNP on Iraqi population.

The rs6152 is a silent SNP located in exon 1 on chromosome $\mathrm{X}$, it's a single nucleotide variant $(\mathrm{G}>\mathrm{A})$ in the androgen receptor gene that does not produce new amino acid at the position 211 of the protein, it has shown that although it's a silent SNP it has a functional effect by modifying the co translational folding and the tridimentional structure of protein ${ }^{(11)}$. The distribution of genotype alleles frequency presented in table (4-2)

Table (4) the genotype and allele frequencies of rs6152 SNP in exon 1 of androgen receptor gene

\begin{tabular}{|c|c|c|c|c|c|c|c|}
\hline \multirow{2}{*}{ Group } & \multicolumn{2}{|c|}{ Control } & \multicolumn{2}{|c|}{ Female with RSA } & \multirow{2}{*}{$\chi^{2}$} & \multirow{2}{*}{ OR } & \multirow{2}{*}{ CI } \\
\hline & No. & Percentage & No. & Percentage & & & \\
\hline GG & 21 & $42 \%$ & 32 & $64 \%$ & $8.52 * *$ & 1.27 & $0.82-1.59$ \\
\hline GA & 10 & $20 \%$ & 6 & $12 \%$ & $4.38 *$ & 0.658 & $0.78-1.64$ \\
\hline $\mathrm{AA}$ & 19 & $38 \%$ & 12 & $24 \%$ & $5.02 *$ & 0.783 & $0.85-1.60$ \\
\hline \multicolumn{8}{|c|}{ Allele frequency } \\
\hline G & \multicolumn{2}{|c|}{0.52} & \multicolumn{2}{|c|}{0.70} & -- & -- & -- \\
\hline A & \multicolumn{2}{|c|}{0.48} & \multicolumn{2}{|c|}{0.30} & -- & -- & -- \\
\hline
\end{tabular}

$*(\mathrm{P}<0.05),{ }^{* *}(\mathrm{P}<0.01)$.

The frequency of wild GG genotype was significantly $(\mathrm{p}<0.01)$ higher in female with RSA than in apparently healthy subjects $(64 \%$ versus $42 \%$, respectively, $\chi 2=$ $8.52, \mathrm{OR}=1.27, \mathrm{p}<0.01)$. In contrast, the frequency of heterozygous GA genotype was significantly $(\mathrm{p}<0.05)$ lower in female with RSA when in comparison with apparently healthy subjects ( $12 \%$ versus $20 \%$, respectively, $\chi 2=4.38, \mathrm{OR}=0.658, \mathrm{p}<0.05)$. The $\mathrm{AA}$ genotype was significantly lower in female with RSA when in comparison with apparently healthy subjects ( $24 \%$ versus $38 \%$, respectively, $\chi 2=4.5 .02, \mathrm{OR}=0.783$, $\mathrm{p}<0.05)$. 


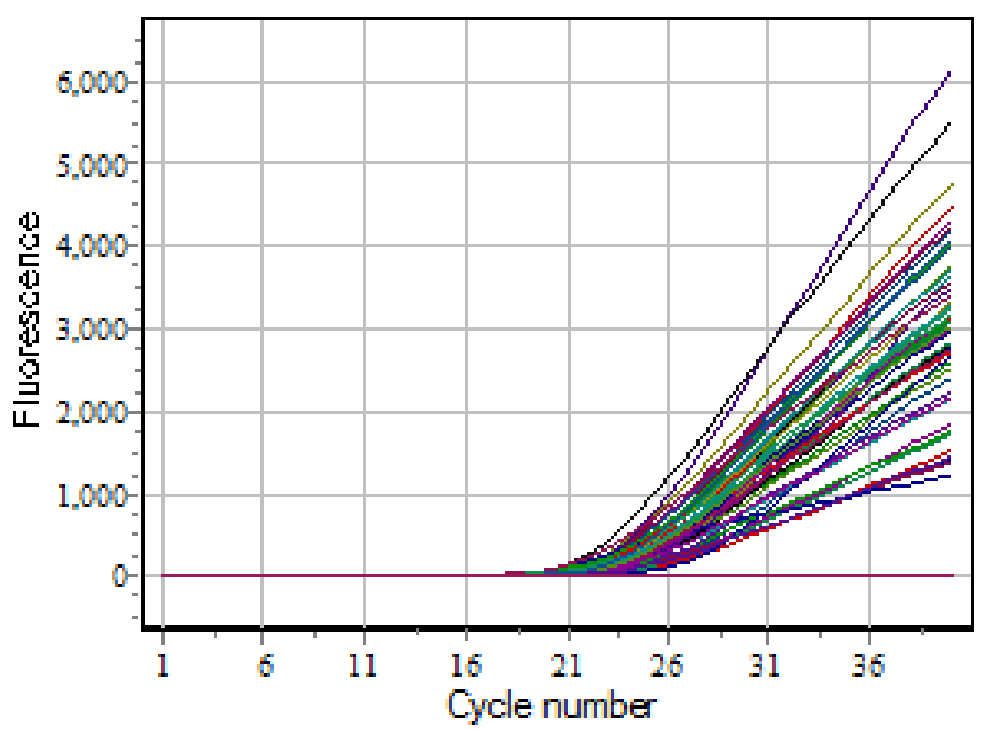

Figure (1) FAM (curves of G allele)

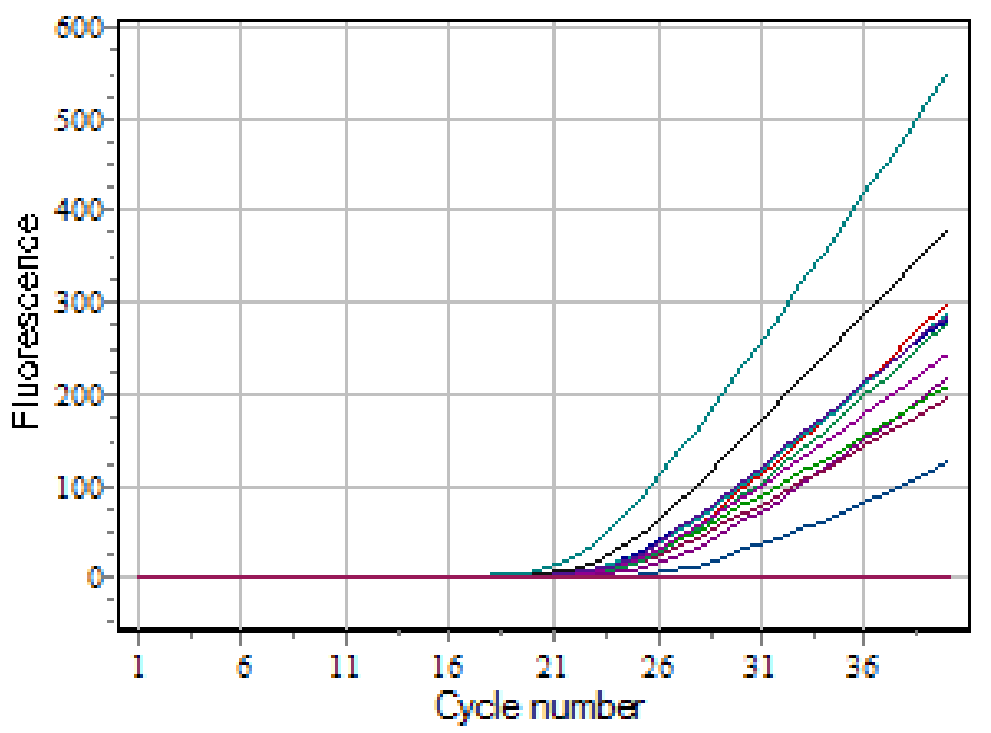

Figure (2) HEX (curves of A allele)

The Gene expression of Androgen receptor gene: The values of $\mathrm{Ct}, \Delta \mathrm{Ct}$ and $2^{-\Delta \mathrm{Ct}}$ of androgen receptor gene for apparently healthy female and female with RSA are shown in table (5).
The means of $\mathrm{Ct}$ value of androgen receptor gene show non-significant difference apparently healthy female and female with RSA, they were $33.16 \pm 0.12$ and $33.49 \pm 0.12$ for apparently healthy female and female with RSA, respectively.

Table (5) Comparison between the study groups in $\mathrm{Ct}, \Delta \mathrm{Ct}$ and $2^{-\Delta \mathrm{Ct}}$ of androgen receptor gene (Means $\pm \mathrm{SD}$ ).

\begin{tabular}{|l|c|c|c|}
\hline Group & Ct Means of androgen receptor gene & $\mathbf{\Delta} \mathbf{C t}$ & $\mathbf{2}^{\text {- } \mathbf{c t}}$ \\
\hline Control & $33.16 \pm 0.12$ & 12.77 & 1.43 \\
\hline Aborted female & $33.49 \pm 0.12$ & 12.96 & 1.25 \\
\hline LSD & $0.337 \mathrm{NS}$ & $0.556 \mathrm{NS}$ & $1.261 \mathrm{NS}$ \\
\hline P -value & 0.055 & 0.749 & 0.378 \\
\hline
\end{tabular}

$\mathrm{NS}=$ non- significant, $\mathrm{SD}=$ standard deviation 
The results related with the folding of androgen receptor gene expression depending on $2^{-\Delta \mathrm{Ct}}$ and $2^{-\Delta \Delta \mathrm{Ct}}$ method are presented in table (6). As shown in table (6) there was none significant decrease in the gene expression of androgen receptor gene depending on the $2^{-\Delta \mathrm{Ct}}$ method, it was 0.87 in females with RSA while it was 1 in control. Also the findings confirmed by calculating the fold depending on $2^{-\Delta \Delta \mathrm{Ct}}$ method.

Table (6): Fold of androgen receptor gene expression depending on $2^{-\Delta \mathrm{Ct}}$ and $2^{-\Delta \Delta \mathrm{Ct}}$ method

\begin{tabular}{|l|c|c|c|}
\hline \multirow{2}{*}{ Parameters } & \multicolumn{3}{|c|}{$\mathbf{2}^{-\Delta \mathrm{Ct}}$} \\
\cline { 2 - 4 } & \multicolumn{3}{|c|}{ Groups } \\
\cline { 2 - 4 } & Control & Patients & P -value \\
\hline $2^{-\Delta \mathrm{Ct}}$ Target & 1.43 & 1.25 & $0.378 \mathrm{NS}$ \\
\hline Experiment/control & $1.43 / 1.43$ & $1.25 / 1.43$ & $0.9 \mathrm{NS}$ \\
\hline Fold of gene expression & 1 & 0.87 & \multicolumn{2}{|c|}{} \\
\hline \multirow{3}{*}{ Parameters } & \multicolumn{3}{|c|}{$2^{-\Delta \Delta \mathrm{Ct}}$} \\
\cline { 2 - 4 } & \multicolumn{3}{|c|}{ Groups } \\
\cline { 2 - 4 } & Control & Patients & $1.00 \mathrm{NS}$ \\
\hline$\Delta \mathrm{Ct}$ Calibrator & 11.7 & 11.7 & $0.87 \mathrm{NS}$ \\
\hline$\Delta \Delta \mathrm{Ct}$ & 1.07 & 1.26 & $0.84 \mathrm{NS}$ \\
\hline $2-\Delta \Delta \mathrm{Ct}$ & 0.47 & 0.41 & ---------- \\
\hline Experiment/control & $0.47 / 0.47$ & $0.41 / 0.47$ & $0.9 \mathrm{NS}$ \\
\hline Fold of gene expression & 1 & 0.87 & \\
\hline
\end{tabular}

\section{Discussion}

The development of RSA cases may be controlled by diverse hereditary pathways, it was reported that RSA is associated with different genes products that involve in biological pathways ${ }^{(12)}$. Many studies were investigating whether the polymorphism of different genes could contribute to RSA progression ${ }^{(13)}$. Androgen receptor gene polymorphism is a good candidate gene because it acts in many tissues. The results of the study showed that the wild type GG genotype is related with the risk of RSA while the heterozygous GA and mutant genotype AA are considering as protective factors. This result disagrees with results of the same SNP on Mexican population which proposed that the heterozygous GA and mutant homozygous were more frequent in patients ${ }^{(14)}$. In Iranian and Greek populations, the heterozygous GA is association with the risk factor of RSA and the present of A allele is related with abortion ${ }^{(13,15)}$. In study on Saudi's women the finding confirmed that there were no association between the SNP and the occurrence of $\operatorname{RSA}^{(16)}$.

The expression of AR in the uterine endometrium during early pregnancy and decidualization is relatively under investigated in, immunohistochemically study on the expression of AR in uteri of mice showed that decrease in the expression during decidualization stage (17). In human androgen receptor expresses in many tissues and its expression varies depending on the age, development and malignant transformation ${ }^{(18)}$. In the endometrium of human, the expression of AR increase in proliferative phase followed by decline in the level through the secretory phase of the cycle ${ }^{(19)}$. During early pregnancy, AR still noticeable in the stroma and decidua of uterus ${ }^{(20)}$.

The down regulation of AR during decidualization may be beneficial to the proliferation and differentiation of stromal cells and embryo implantation ${ }^{(21)}$.

\section{Conflict of Interest: None}

Funding: Self

Ethical Clearance: Not required

\section{References}

1. Pokale, Yamini Sharad. Recurrent miscarriage. International research journal of medical sciences. 
Vol 3(9),13-19 2015.

2. Traish Abdulmaged M, Noel Kim,. Kweonsik Min, Ricardo Munarriz, Irwin Goldstein. Role of androgens in female genital sexual arousal: receptor expression, structure, and function. ANDROGEN PRODUCTION AND MECHANISMS| VOLUME 2002. 77, 4, 11-18.

3. MacLean HE, Moore AJ, Sastra SA, Morris HA, Ghasem-Zadeh A, Rana K, et al. DNAbindingdependent androgen receptor signaling contributes to gender differences and has physiological actions in males and females. J Endocrinol 2010. 206:93-103

4. Guay, A., Munarriz, R., Jacobson, J., Talakoub, L., Traish, A., Quirk, F., Goldstein, I., \& Spark, R. Serum androgen levels in healthy premenopausal women with and without sexual dysfunction: Part A. Serum androgen levels in women aged 20-49 years with no complaints of sexual dysfunction. International journal of impotence research, 2004. 16(2), 112-120.

5. Eriksson C. J. Peter, Bettina von der Pahlen, Taisto Sarkola, Kaija Seppä. OESTRADIOL AND HUMAN MALE ALCOHOL-RELATED AGGRESSION, Alcohol and Alcoholism, 2003. Volume 38, Issue 6, Pages 589-

6. Chang C, Saltzman A, Yeh S, Young W, Keller E, Lee HJ, Wang C, Mizokami A. Androgen receptor: an overview. Crit Rev Eukaryot Gene Expr. 1995. 5:97-125.

7. Rana K, Davey RA, Zajac JD. Human androgen deficiency: insights gained from androgen receptor knockout mouse models. Asian J Androl; 2014. 16:169- 77

8. Burger H. G. Androgen production in women. Fertility and sterility, 2002. 77 Suppl 4, S3-S5. https://doi.org/10.1016/s0015-0282(02)02985-0.

9. Davey, R. A., \& Grossmann, M. Androgen Receptor Structure, Function and Biology: From Bench to Bedside. The Clinical biochemist. Reviews, 2016. 37(1), 3-15.

10. SAS. Statistical Analysis System, User's Guide. Statistical. Version 9.1 $1^{\text {th }}$ ed. SAS. Inst. Inc. Cary. N.C. USA. 2012.

11. Kimchi-Sarfaty C, Oh JM, Kim IW, Sauna ZE, Calcagno AM, Ambudkar SV, et al. A Bsilent.
Polymorphism in the MDR1 gene changes substrate specificity. Science. 2007. 26(315):525-8.

12. Tempfer C, Unfried G, Zeillinger R, Hefler L, Nagele F, Huber JC. Endothelial nitric oxide synthase gene polymorphism in women with idiopathic recurrent miscarriage. Hum Reprod. 2001.16(8):1644-7. doi: 10.1093/humrep/16.8.1644

13. Buchholz T, Lohse P, Kosian E, Thaler CJ. Vasoconstrictively acting AT1R A1166C and NOS3 4/5 polymorphisms in recurrent spontaneous abortions (RSA) Am J Reprod Immunol. 2004. 51(5):323-8. doi: 10.1111/j.16000897.2004.00163.x

14. Porras-Dorantes, Á., Brambila-Tapia, A., LazcanoCastellanos, A. B., Da Silva-José, T. D., JuárezOsuna, J. A., \& García-Ortiz, J. E. Association between G1733A (rs6152) polymorphism in androgen receptor gene and recurrent spontaneous abortions in Mexican, 2017.

15. Giagulli, V., Carbone, M.D., Pergola, G., Guastamacchia, E., Resta, F., Licchelli, B., Sabbá, C., \& Triggiani, V. Could androgen receptor gene CAG tract polymorphism affect spermatogenesis in men with idiopathic infertility? Journal of Assisted Reproduction and Genetics, 31, 689-697. population. Journal of assisted reproduction and genetics, 2014. 34(10),1303-1306.

16. Alkhuriji, A.F., Alomar, S.Y., Babay,Z.A., \& Khalil, M.I. G 1733 A Polymorphism of the Androgen Receptor Gene and Recurrent Spontaneous Abortion in Saudi' s Women. American Family Physician, 2017.76(9):1341-1346.

17. Xu, J., Li, M., Zhang, L., Xiong, H., Lai, L., Guo, M., Zong, T., Zhang, D., Yang, B., Wu, L., Tang, M., \& Kuang, H. Expression and regulation of androgen receptor in the mouse uterus during early pregnancy and decidualization. Molecular reproduction and development, 2015. 82(11), 898906.

18. Matsumoto T, Shiina H, Kawano H, Sato T, Kato $\mathrm{S}$. Androgen receptor functions in male and female physiology. J Steroid Biochem Mol Biol 2008. 109:236241

19. Mertens HJ, Heineman MJ, Theunissen PH, de Jong FH, Evers JL. Androgen, estrogen and progesterone receptor expression in the human uterus during the menstrual cycle. Eur J Obstet Gynecol Reprod Biol 2001. 98:5865. 
20. Critchley HO, Saunders PT. Hormone receptor dynamics in a receptive human endometrium. Reprod Sci 2009. 16:191199
21. Tuckerman EM, Okon MA, Li T, Laird SM. Do androgens have a direct effect on endometrial function? An in vitro study. Fertil Steril 2000. 74:771-779. 